How to cite this article:

Basah, N. H. (2019). Factors that influence the quality of relationship between exporters and foreign intermediaries in relation to SMEs' export performance. Journal of International Studies, 15, 87-103. https://doi.org/10.32890/jis2019.15.6

\title{
Factors that Influence the Quality of Relationship between Exporters and Foreign Intermediaries in Relation to SMEs' Export Performance
}

\author{
Norliza Hamir Basah \\ School of International Studies, \\ Univesiti Utara Malaysia, Malaysia \\ hnorliza@uum.edu.my \\ DOI: https://doi.org/10.32890/jis2019.15.6 \\ Received: 20/2/2019 \\ Revised: 1/10/2019 \\ Accepted: 7/10/2019 \\ Published: 31/12/2019
}

\begin{abstract}
This study intended to investigate factors that influence the relationship quality between Malaysia SME exporters and foreign intermediaries. This paper drew insights from two integrating theories, namely the social capital theory (SCT) and internationalization process (IP) theory, to evaluate the synergistic consequences of several constructs, such as cultural similarity, effective communication, knowledge sharing and trust that are related to export performance. The model was tested using Structural Equation Modelling (SEM) via Smart PLS on a sample of 203 SME exporters in Malaysia. Findings revealed that all hypotheses were supported. This study revealed that cultural similarity is a catalyst in the internationalization process as well as how it influences effective communication and knowledge sharing, thus, the impetus to build trust, which finally reflects the performance outcomes. The findings supported the application of underpinning theories and their tenets in explaining Malaysian SMEs' export performance with the collaboration of foreign intermediaries.
\end{abstract}

Keywords: SME, export performance, intermediaries, relationship quality, cultural similarity.

\section{Introduction}

Changes in business structure due to rapid globalization and high standards of technology have compelled SMEs around the world to establish business networks and change the selection of entry modes for the success of new international ventures (Pinho, 2016; Ripolles 
et al., 2012). Strong networking with competent foreign intermediaries can provide SMEs with adequate competitive advantage as well as allow them to penetrate foreign markets and surpass the complexities inherent in exporting and ultimately succeed in managing their foreign businesses. As a middleman, export intermediaries play a crucial role in international trade as a transactional link between individuals and organizations (Peng \& York, 2001). Balabanis (2000) claims that intermediaries can help exporters to distinguish between customers and distribution infrastructure providers, help exporters bridge the knowledge gap, as well as reduce risks and uncertainties when operating in a foreign market. As such, an international exchange relationship strongly depends on the quality of the relationship between both sides, which is one of the non-price competition instruments. Hence, establishing a working partnership is indeed crucial for small businesses to enhance their competitive capability since this capability is limited in SMEs due to scarcity of tangible and intangible resources (Saleh \& Ndubisi, 2011).

In this sense, smaller firms in Malaysia face several limitations when internalizing their firms, which the largest barrier being financial resources $(75 \%)$, followed by resource constraints $(69 \%)$, lack of management skill (63\%), problematic managers/entrepreneurs (56\%), incompetent R\&D (56\%), political interference (31\%), and psychological distance (25\%) (Zizah et al., 2014). Thus, for these reasons, SMEs should look into this prospect as an effort to establish close relationships, otherwise known as quality relationship, with foreign intermediaries in export markets for international development purposes and to overcome challenges. This is because foreign intermediaries are known to have an aptitude to reduce such costs and possess specific knowledge for doing business in an unfamiliar foreign market. Therefore, inter-organizational relationship is crucial as a critical component in the strategic formulation of global business operations.

Despite to its importance, several major issues have also emerged when SME exporters used the services of foreign intermediaries. First, cultural factors can be a major contributor to failure in trans-border partnerships. This is consistent with the view of some scholars and practitioners who claim that national and organizational cultures play a crucial role in determining a successful international business relationship (Xie et al., 2016; Meirovich, 2012). For example, differences in cultural background between SME exporters and intermediaries can positively influence the establishment of a desirable export performance. Second, conflict can arise when exporters start using the services of intermediaries because exporters will lose their control in respect of marketing strategy, selection of customers, foreign operations and managing of resources (Kuhlmeir \& David, 2010). Third, the increase in transactional costs when exporters engage the services of intermediaries. Thus, social capital is critical when emphasizing the development of a high-quality relationship between exporters and their intermediaries, perhaps to avoid such conflicts and reduce costs. Among the key facets of these relational dimensions are trust, which plays an important role (Nahapiet \& Goshal, 1998) and the quality of network relationships (Pinho, 2016). Concerning the trust construct in this study, it specifies that exporters and intermediaries can commit to a high-quality relationship, develop shared meanings as well as a universal 
language and a common apparition when they trust each other. However, there is a lack of studies focusing on the effect of culture on relational factors and export performance, particularly, in the context of small businesses (Robson et al., 2012). In tandem with the research gaps, this study attempted to examine the effect of cultural similarity that facilitates effective communication, knowledge sharing and trust on export performance as well as how cultural similarity can influence export performance.

\section{Malaysia's Export Performance}

Malaysian SMEs' contribution in terms of exports is still low despite their large numbers, which stands at merely $21.2 \%$ (among over 900,000 local SMEs). In addition, the SME master plan envisions that the figure will rise to $23 \%$ by 2020 (MATRADE, 2017). As claimed by Biamiatzi and Kirchmaier (2014), factors that contribute to SME growth, particularly regarding exports, are still in need of further research because in order to achieve profitability, all SMEs should export (Stouraitis, Harun \& Kyritsis, 2015). Referring to the comparison of large firms in Malaysia, SMEs lack behind due to limited resources and capabilities for acquiring information, which forces them to venture into exports with the government's supervision (Ayob \& Freixanet, 2014). Approximately 95\% of Malaysian SMEs focus on local businesses, which represent close to $99 \%$ of total establishments in the country (Lee, 2018) Malaysian SMEs only contributed 38.3\% to the country's GDP in 2016, which is a slight increment of 1.7\% compared to 2017 (MATRADE, 2017). In the manufacturing sector, SMEs' value added recorded a growth of $4.8 \%$, which was slightly down compared to 2015 (6\%) (SME Corporation, 2017). This shows that Malaysian SMEs have broadened their export base but the intensity of involvement in export activities remains low (MATRADE, 2014). Therefore, continuous support from the government as well as expert advice from intermediaries can ensure SME exporters accomplish the next stage in the internationalization process and avoid export withdrawal.

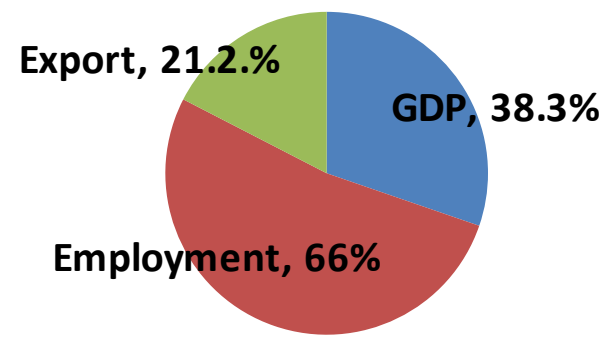

Figure 1. SMEs Contribution to the Malaysian Economy

Source: MATRADE (2018) 


\section{Issues Pertaining to Export Performance}

Generally, export performance is defined as a firm's level of achievement in its export activities in foreign markets (Shoham, 1996). However, until date there is no consistent accepted definition of what constitutes a construct (Navarro et al., 2010; Cavusgil \& Zou, 1994). Basically, the construct is multifaceted, and the measurement and assessment depends on contextual factors, primarily concerning the research method adopted, specifically the business and target audience (Pinho, 2016; Katsikeas et al., 2000). In fact, performance accomplishment is usually perceived differently by individual firms, whereby, what might be considered a staggering success by some companies might be deemed as a failure by others. Bourgeois (1980) suggested that managers have a tendency to analysis the performance themselves rather than the objective values in order to make their own decision. In an extensive literature review, indicators such as export performance can be categorized into financial (objective) and non-financial (subjective) elements. Sousa (2004) claimed that indicators that are primarily based on absolute numerical values are categorized as objective, whilst, the concepts that require perceptual or attitudinal input are consider as subjective. Both the objective and subjective assessments can be carried out through secondary or primary sources. In other words, academicians tend to use subjective measures compared to objective measures due to several factors. Such as the difficulty in obtaining financial export performance data, firms' unwillingness to reveal absolute values and lack of specific information regarding export financial reports (Lages \& Sousa, 2010). Therefore, it is generally agreed that export performance is multi-dimensional and can be conceptualized and operationalized in numerous ways due to several ad hoc assessment methods emphasizing on varying performance dimensions (Diamantopoulos \& Winklhofer, 2001).

\section{Literature Review: Factors that Trigger Export Performance}

Existing studies demonstrate mixed results and inconsistencies regarding the relationship between cultural elements and performance. This is evident in arguments by some scholars whereby cultural distance promotes negative results, while others yield totally contrasting findings, such as differences in culture have a positive relationship with performance (Krishnan et al., 1997). For example, Pothukuchi et al. (2002) claimed that cultural distance positively impacts the efficiency and competitiveness of IJVs. The reason for these contradicting findings is due to the multilevel nature of culture (Pauline et al., 2013), congruency of economic and psychological performance (Pothukuchi et al., 2002) and the varying concept and methodology of the cultural distance construct (Shenkar, 2001). However, Aronson and Carlsmith (1962) and Festinger (1957) noted that the cognitive dissonance theory implies that people usually support information that is consistent with their thoughts and norms and will only gather data that reinforces their beliefs (Fiske \& Neuberg, 1990). Hence, many scholars emphasize that cultural similarity is important as it encourages people to 
cooperate and work together to develop a high-quality relationship as well as to enhance export performance. This notion was supported by Sarkar et al. (2001), who confirmed that exporters produce better performance in the presence of cultural similarity. Sirmon and Lane (2004) stressed that a similar cultural background can facilitate compromises in which both members abandon their preferred problem-solving approaches and efficiently eradicate a significant amount of their tacit knowledge. Imitating another cultural behaviour can backfire and could be very difficult to follow (Francis, 1991). Therefore, due to the inconsistencies in the findings, this study attempted to fulfil this gap.

\section{Cultural Similarity, Effective Communication and Knowledge Sharing}

Johanson and Vahle (1977) popularised the IP theory and claimed that firms prefer to attempt markets with cultural similarity in their primary stage of internationalization so that they can freely communicate with their partners and obtain knowledge by engaging in foreign business relationship (Johanson \& Vahlne, 1990; Saleh et al., 2014). Cultural similarity is totally linked to communication, knowledge flow and innovation because similar business practices, morals, ethics, and styles lead to easy communication, learning and the knowledge gathering process (Swift, 1999). It is crucial to remove barriers in relational exchange and communication (Hoffmann, Rottger, Ingenhoff \& Hamidati, 2016) in order to enhance the effectiveness and understanding of such relationships (Swift, 1999). This is because easy and effective communication helps exporters and intermediaries to exchange information and share inescapable situations that go toward enhancing successful channel relationships (LaBahn \& Harich, 1997). However, pertinent literature reviews show that there is a lack of studies on cultural similarity and its impact on the relationship between exporters and intermediaries concerning international exchange processes in general and export performance, in particular. Previous studies have suggested that cultural closeness is a contributory factor to psychological closeness. Nevertheless, very few studies have validated this finding (Saleh, 2014) resulting in consistent findings. This in turn, implies the significance of the effects on the exporter-intermediary relationship and should be investigated further.

\section{Cultural Similarity and Trust}

Despite the importance of SMEs preferring psychological closeness, social networking is also crucial for exporters and intermediaries when penetrating export markets and developing the necessary strategies (Wheelan, 2016; Ibeh \& Kasem, 2011) and information that can increase flexibility in a highly volatile marketplace (Kogut \& Kulatilaka, 1994; Peng \& Ilinitch, 1998). This view has been acknowledged in the Social Capital Theory (SCT), which states that social capital is linked to sharing resources that are rare, valuable, inimitable and non-substitutable opening up novel opportunities for individuals and organizations alike (Burt, 1992; Tsai \& Ghoshal, 1998; Yli-Renko et al., 2001; Inkpen \& Tsang, 2005). Thus, it is anticipated that social capital could impact a SME's performance. The SCT focuses on associations and personal ties that play a significant role in the transfer 
of valuable information. It bridges ties that link people in a variety of social groups to classify foreign market opportunities that facilitate commercial transactions with foreign intermediaries (Ellis \& Pecotich, 2001; Harris \& Wheeler, 2005). However, social capital cannot be generated instantly, as a certain period is necessary to support the willingness of managers to make relationship-specific investments that are essential to build trust (Pinho, 2016). Trust between partners is very important and can develop through open and honest communications with partners, including all marketing decisions, including pricing, seeking market information and providing feedback (Anderson \& Narus, 1996). In regard to the relational dimension, it consists of emotional and affective elements within the social network. Several authors claim that this element is fundamental to the social capital concept (Lew et al., 2013). In the context of the exporter-intermediary relationship, trust has been found to be the key facet of the relational dimension (Nahapiet \& Ghoshal, 1998). According to Pinho (2013), trust is also the most critical factor in the commencement of a relationship based on mutual expectations by both parties.

In addition, Golbeck (2009) revealed that similarity can be an impetus to trust, which is related to whether a user should trust another person. Even though studies regarding the impact of cross-border culture and trust relationship are being undertaken, relatively limited studies have focused on cultural similarity as an antecedent of trust. In fact, existing literature has mostly iterated that exporters tend to look for trusted partners with cultural similarity in the market, which in turn, leads to better export performance. Cultural similarity can be deemed as a mechanism for international business actors to communicate effectively, share knowledge, and gather experience from culturally proximal markets to accelerate business growth and expansion, particularly in the initial stage of SME development, to infiltrate the overseas market. The business expansion will be more efficient due to greater acquisition of digitalised information resources and greater digitizing of resource initiatives that can be achieved by using the sophisticated technology (Wahid, Saidin \& Arif, 2018).

\section{Trust and Performance}

According to Morgan and Hunt (1994), trust is critical in the inter-organizational context and has been extensively employed in building relational governance in a partnership. Even though trust is widely used as a determinant of a successful relationship, there is a lack of studies aimed at investigating the functional impact of trust on the performance of interfirm exchange (Musteen, Francis \& Datta, 2010). Authors in the international business field have claimed that there is a lack in studies that examine the relationship between trust and performance (e.g., Pinho, 2016; Inkpen \& Currall, 1998; Sakoa \& Helperb, 1998; Aulakh, Kotabe \& Sahay, 1996; Silva et al., 2012), particularly concerning small businesses. Although previous literature has considered relationship quality at the national level, there is a lack of empirical research that explains the consequences of relationship quality on export performance at the international level and the classification of SMEs based on the dimensions of relational quality. Due to this constraint, this study intended to examine the effect of cultural similarity on trust and export performance. 


\section{Conceptual Framework}

This study attempted to investigate how relationships developed between SME exporters and their intermediaries by focusing on an Asian country, which is Malaysia, since previous studies had concentrated more on developed nations. Figure 2 illustrates the conceptual framework used in this current study. The pertinent independent variables in the framework are cultural similarity, effective communication, knowledge sharing and trust. The dependent variable was export performance.

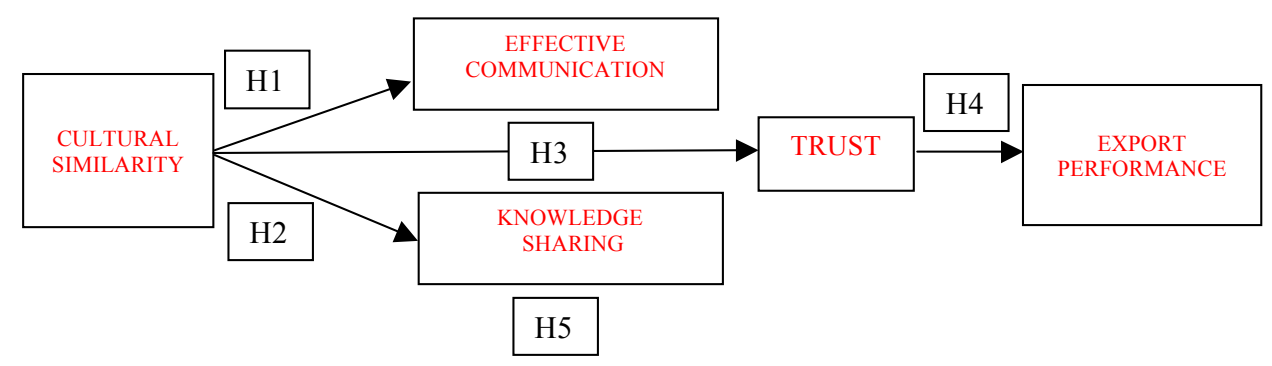

Figure 2. Conceptual Framework

\section{Research Methodology}

This study adopted a positivistic paradigm, which quantified and analysed data, as well as tested the relationship between theory and research (Cresswell, 2013). In other words, this study employed the quantitative approach, in which relevant theories were operationalised by examining factors that influenced the relationship between exporters and intermediaries (i.e., cultural similarity, effective communication and knowledge sharing) and the quality of that relationship (i.e., trust) towards export performance. In addition, a quantitative research design was employed due to its use of deductive reasoning, where a greater amount of data is used to validate the relationship of a proposed framework (Zikmund, Babin, Carr \& Griffin, 2013).

\section{Sample Profile}

Data were compiled from SME Corporations and crosschecked with MATRADE. There were 14000 SMEs from numerous categories identified in the databases. Since this study concentrated on SMEs that manufacture and export, the verification of databases is necessary to ensure that only active exporters are considered. Hence, MATRADE was engaged for crosschecking purposes. There were 2500 SMEs involved in exporting activities and the samples were determined by using the purposive sampling method. A purposive sample is 
a non-probability sample that is selected based on characteristics of a population and the objective of the study. Purposive sampling differs from convenience sampling and is also known as judgmental, selective, or subjective sampling.

Based on the population, only 1000 SMEs that manufacture and export were found to fulfil the criteria established by this study; which involved and the use of intermediary services. Therefore, questionnaires in Malay and English languages were sent to the sample companies and addressed to target respondents consisting of export managers, chief executive officers (CEO) and managing directors of SME exporting firms. 229 questionnaires were received; however, only 203 were accepted for analysis. As for non-response bias (T-test), a comparison was made between early and late respondents, as recommended by Armstrong and Overton (1977). However, no significant differences were found between early and late responses.

\section{Data Analysis}

In regard to the research model and hypotheses, structural equation modelling (SEM) and partial least squares (PLS) approaches were used in this study to verify the measurement's goodness of fit. This software is an extended version of the general linear model (GLM) that enables a study to simultaneously test a set of regression equations. Hence, the Smart PLS 3.0 beta version was used (Ringle et al., 2005) since it is appropriate for causal analysis in complex contexts where theoretical knowledge is scant (Wold, 1982). Data in this study were analysed using PLS in two stages (Chin, 2010), consisting of the assessment and measurement models. First, assessment of the measurement model was carried out, including item reliability, convergent and discriminant validity as well as a further assessment on the structural model. The weights and loading items indicate the strengths of measures, while the estimated path coefficient represents the strength and the sign of the theoretical relationship.

\section{Results}

\section{Assessment of the Measurement Model}

Table 1 illustrates the item's reliability as suggested by Hair et al. (2010). The results show that all appropriate factor loadings are greater than 0.5 and a very conservative Composite reliability (CR) cut-off level for all constructs are higher than 0.70 (Nunnally, 1967). Furthermore, the AVE values of all constructs exceed 0.50 (ranging from 0.56 to 0.78 ). Convergence validity was measured by examining the average variance extracted. Results further indicate that the statistical test (convergent validity) has fulfilled the requirements stipulated by Hair et al. (2010). Table 1 summarizes the outcome of the measurement models. Discriminant validity is the degree to which different constructs diverge from one 
another. As a rule of thumb, discriminant validity is acceptable when the square root of the construct's AVE is higher than its correlation with other constructs (Fornell \& Larcker, 1981). This procedure clearly shows that the correlation of all constructs is greater than the threshold of the correlation of any specific construct with any other construct, thus, it portrays the discriminant validity.

Table 1

Assessment of Measurement Items

\begin{tabular}{|c|c|c|c|c|}
\hline Model Construct & Measurement Item & Loadings & $\mathrm{AVE}^{\mathrm{x}}$ & $\mathrm{CR}^{\mathrm{y}}$ \\
\hline \multirow{5}{*}{ Cultural Similarity } & B8a & 0.782 & \multirow{5}{*}{0.685} & \multirow{5}{*}{0.915} \\
\hline & $\mathrm{B} 8 \mathrm{~b}$ & 0.848 & & \\
\hline & $\mathrm{B} 8 \mathrm{c}$ & 0.844 & & \\
\hline & $\mathrm{B} 8 \mathrm{~d}$ & 0.848 & & \\
\hline & $\mathrm{B} 8 \mathrm{e}$ & 0.815 & & \\
\hline \multirow{8}{*}{ Effective Communication } & B9a & 0.721 & \multirow{8}{*}{0.561} & \multirow{8}{*}{0.910} \\
\hline & B9b & 0.764 & & \\
\hline & B9c & 0.821 & & \\
\hline & B9d & 0.797 & & \\
\hline & B9e & 0.630 & & \\
\hline & B9f & 0.765 & & \\
\hline & B9g & 0.716 & & \\
\hline & B9h & 0.760 & & \\
\hline \multirow{6}{*}{ Export Performance } & $\mathrm{D} 15 \mathrm{a}$ & 0.907 & \multirow{6}{*}{0.781} & \multirow{6}{*}{0.956} \\
\hline & $\mathrm{D} 15 \mathrm{~b}$ & 0.894 & & \\
\hline & $\mathrm{D} 15 \mathrm{c}$ & 0.896 & & \\
\hline & D15d & 0.888 & & \\
\hline & $\mathrm{D} 15 \mathrm{e}$ & 0.874 & & \\
\hline & $\mathrm{D} 15 \mathrm{f}$ & 0.845 & & \\
\hline
\end{tabular}




\begin{tabular}{rcccc}
\hline Model Construct & Measurement Item & Loadings & AVE $^{\mathrm{x}}$ & $\mathrm{CR}^{\mathrm{y}}$ \\
\hline Bnowledge Sharing & B10b & 0.750 & & \\
& B10c & 0.854 & & \\
& B10d & 0.886 & 0.722 & 0.939 \\
B10e & 0.896 & & \\
B10f & 0.852 & \\
\hline C11a & 0.827 & & \\
C11b & 0.861 & & \\
C11c & 0.864 & \\
C11d & 0.846 & 0.693 \\
C11e & 0.853 & & \\
C11f & 0.865 & & \\
& C11g & 0.837 & & \\
\hline
\end{tabular}

Table 2

Discriminant Validity Construct

\begin{tabular}{llllll}
\hline & Cultural & & Effective & Export & Knowledge \\
& & & & & \\
Trust & & & & & \\
& & & & & \\
& & Similarity & & communication & \\
CS & 0.828 & & & & \\
EFC & 0.455 & 0.749 & & 0.849 & \\
EXP & 0.231 & 0.263 & 0.884 & 0.598 & 0.832 \\
KS & 0.375 & 0.583 & 0.401 & & \\
TR & 0.469 & 0.634 & 0.406 & & \\
\hline
\end{tabular}

Note: Diagonal indicates $\sqrt{\mathrm{AVE}}$; off diagonal indicates correlations between constructs: Where, $\mathrm{COM}=$ Commitment,$\quad \mathrm{COO}=$ Cooperation,$\quad \mathrm{CS}=$ Cultural Similarity, $\mathrm{TR}=$ Trust,$\quad \mathrm{EXP}=$ Export Performance. 


\section{Assessment of the structural model}

Hair et al. (2010) had recommended a five-step procedure to assess a structural model. It consists of identifying collinearity issues, evaluating the path-coefficient, assessing the $\mathrm{r}^{2}$ values, as well as assessing the effect size $\left(f^{2}\right)$ and predictive relevance ( $q^{2}$ value). Details of the results are presented in Table 1, which indicates that all relationships have a significant relationship at a significance level of $\mathrm{p}<0.01$. The results also indicate that the similarity in culture between exporters and foreign intermediaries can augment export performance $(\beta=0.207, \mathrm{p}<0.01)$. The effect of cultural similarity and effective communication are significantly positive $(\beta=0.455, \mathrm{p}<0.01)$ between exporters and foreign intermediaries. Hence, $\mathrm{H} 2$ is supported. There is a positive relationship regarding the effect of cultural similarity between exporters and intermediaries based on trust, which has an estimated coefficient of $\beta=0.469$, $t$-value $=13.060$ and a significant $p$ value of $<0.01$. The link between cultural similarity and knowledge sharing is also supported $(\beta=0.375, \mathrm{t}=8.741$ with a $\mathrm{p}$ value of $<0.01)$. The result supports the relationship between effective communication and trust with $\mathrm{t}$-value $=14.850$ and $\mathrm{p}$-value $<0.01$. Hypothesis 5 involves the link between trust and export performance between exporters and foreign intermediaries, in which the link has a positive influence at a significance level of $p$-value $<0.01$ with $\beta=0.395$ and $\mathrm{t}$-value $=10.867$.

Table 3

\section{Structural Relationship}

\begin{tabular}{|c|c|c|c|c|c|c|}
\hline \multirow[t]{2}{*}{ Hypotheses } & \multirow[t]{2}{*}{ Path/Relationship } & \multicolumn{4}{|c|}{ SEM Output-Full Model } & \multirow[t]{2}{*}{ Results } \\
\hline & & $\mathrm{B}$ & S.E & $\mathrm{T}$ & $\mathrm{P}$ & \\
\hline H1 & $\begin{array}{l}\text { Cultural Similarity -> } \\
\text { Effective Communication }\end{array}$ & 0.455 & 0.048 & 6.287 & $\mathrm{P}<0.01$ & Supported \\
\hline $\mathrm{H} 2$ & Cultural Similarity $->$ Trust & 0.469 & 0.036 & 13.060 & $\mathrm{P}<0.01$ & Supported \\
\hline $\mathrm{H} 3$ & $\begin{array}{l}\text { Cultural Similarity -> } \\
\text { Knowledge Sharing }\end{array}$ & 0.375 & 0.043 & 8.741 & $\mathrm{P}<0.01$ & Supported \\
\hline $\mathrm{H} 4$ & Trust $->$ Export Performance & 0.395 & 0.036 & 10.867 & $\mathrm{P}<0.01$ & Supported \\
\hline
\end{tabular}

Note: Results supported at significance level $\mathrm{p}<0.05(* *)$ and at $\mathrm{p}<0.01(* * *)$ based on one-tailed $\mathrm{t}$-statistic table, as t-value greater than 1.65 is significant at $\mathrm{p}<0.05$, while $\mathrm{t}$-value at 2.45 or greater is significant at $\mathrm{p}<0.01$. 


\section{Discussion and Conclusion}

This study intended to examine how cultural similarity between SME exporters and their foreign intermediaries affects SMEs' export performance. The theoretical section of this study contains four hypotheses, indicating that all hypotheses are supported by the findings. Briefly, the result indicates that cultural similarity between exporters and their intermediaries has a significantly positive relationship with export performance. It clearly shows that cultural similarity is crucial for improving export performance because cultural similarity can influence the relationship between SME exporters in Malaysia and its foreign intermediaries. This means that exporters are encouraged to develop high-quality relationships with their foreign intermediaries with similar cultural background. These results are consistent with Azar (2014), as well as Sirmon and Lane (2004), who claimed that in order to achieve success, partners should possess similar cultural backgrounds. Besides, this study found that positive relationships based on cultural similarity and effective communications are in line with previous studies. The findings show that cultural similarity between exporters and intermediaries has a strong positive relationship in creating effective communication between them. This result indicates that SME exporters can freely communicate with their intermediaries who have a similar cultural background. This helps to expedite negotiations, leading to effective discussions and impetus for building trust among each other.

Cultural similarity has been found to have a positive relationship with knowledge sharing, thus, supporting H2. The result is consistent with previous studies by Saleh et al. (2014), Blankerburgand Ericksson (2000) and Johanson and Vahlne (1990), where a culturally proximal market is necessary for sharing knowledge in foreign business relationships. Cultural similarity also has a positive effect on trust between exporters and their intermediaries, thus, indicating the support for $\mathrm{H} 3$. The result also confirms that trust has a positive influence on exporters' performance. The findings clearly indicate that in business relationships, trust is verified for developing long-term cooperation in business. Trust between exporters and their intermediaries play a crucial role in dealing with any problem or challenge in foreign markets. Basically, the theoretical underpinnings of this study (SCT and IP theories) are applicable when explaining export performance that results from the relationship between exporters and their intermediaries in the international arena. The findings of this study suggest that an inter-relationship exists between cultural similarity and effective communication, leading to the generation of knowledge sharing as psychological closeness forges strong interdependence (mutual) for both parties (exporters-intermediaries). The results also specify that trust is very important in building and maintain a high quality relationship that contributes to a firm's significant growth, namely in the form of export performance.

\section{Practical and theoretical contributions}

This study contributes to both the underpinning theories as well as provides some useful practical directions to develop a high-quality relationship between SME exporters and their intermediaries. First, the study offers useful guidelines to Malaysian SME exporters when 
working hand-in-hand with intermediaries who possess similar cultural backgrounds. Second, SME exporters need to strengthen networking with foreign intermediaries for survival in a foreign country. Third, this study has constructed a model to show how cultural similarity can lead to better export performance through effective communication, knowledge sharing and trust building in order to develop a high standard network relationship. This study contributes to the existing corpus of knowledge by explaining the internationalization process and social capital theories that facilitate the creation of a high-quality relationship between exporters and intermediaries to best perform best in an international business platform. In short, this study enriches our understanding of how cross-cultural elements and social capital can explain a firm's performance in the context of a working relationship between exporters and local intermediaries.

\section{Limitations and future research}

This study had encountered some limitations that should be addressed by future studies. Firstly, this study only considered the exporters' perspectives, which focused on one side of the dyad. Nevertheless, perceptions could vary across the dyad (skallerud, 2015). Therefore, future studies should be more attentive to the perspectives of both exporters and intermediaries. Secondly, due to the study's scope and inherent constraints, it only focused on exporters' viewpoints in terms of manufacturing rather than service industries. thus, future studies should investigate both perspectives in order to gain a holistic picture and contribute immensely to both parties. Lages et. al. (2005) suggested that in the international context, relationships are critical and much easily affected by cultural, social and other environmental diversities as compared to domestic business relationships. Hence, relationships and findings in this current study may differ due to differences in samples and contexts. Therefore, future studies should focus more in this direction, especially from the emerging economies perspective.

\section{References}

Ahamed, A. J., \& Skallerud, K. (2015). The link between export relationship quality, performance and expectation of continuing the relationship: A South Asia exporters' perspective. International Journal of Emerging Markets, 10(1), 16-3

Aulakh, P. S., Kotabe, M., \& Sahay, A. (1996). Trust and performance in cross-border marketing partnerships: A behavioral approach. Journal of International Business Studies, 27(5), 1005-1032.

Ayob, A. H., \& Freixanet, J. (2014). Insights into public export promotion programs in an emerging economy: The case of Malaysian SMEs. Evaluation and program planning, 46, 38-46.

Anderson, J., \& Narus, J. A. (1996). Rethinking distribution: Adaptive channels. Harvard Business Review, 74(4), 112-120.

Armstrong, J. S., \& Overton, T. S. (1977). Estimating nonresponse bias in mail surveys. Journal of Marketing Research, 14(3), 396-402. 
Aronson, E., \& Carlsmith, J. M. (1962). Performance expectancy as a determinant of actual performance. Journal of Abnormal and Social Psychology, 65(3), 178-182.

Azar, G. (2014). Food cultural distance as a predictor of foreign market selection: The case of Swedish food exporters. Journal of Foods Products Marketing, 20(1), 75-97.

Balabanis, G. I. (2000). Factors affecting export intermediaries service offerings: The British example. Journal of International Business Studies, 31(1), 83-99.

Balabanis, G. I. (2001). The relationship between diversification and performance in export intermediary firms. British Journal of Management, 12(1), 67-84.

Bourgeois, L. J. (1980). Performance and consensus. Strategic Management Journal, 1(3), 227-248.

Cavusgil, S. T., \& Zou, S. (1994). Marketing strategy-performance relationship: An investigation of the empirical link in export market ventures. Journal of Marketing, $58(1), 1-21$.

Chin, W. W., \& Newsted, P. R. (1999). Structural equation modelling analysis with small samples using partial least squares. Statistical Strategies for Small Sample Research. Thousand Oaks, C. A.: Sage Publications.

Cresswell, J. W. (2013). Research design, qualitative, quantitative, and mixed methods, approaches. Thousand Oak, SAGE.

Davis-Kean, P. E. (2005). The influence of parent education and family income on child achievement: The indirect role of parental expectations and the home environment. Journal of Family Psychology, 19(2), 294-304.

Diamantopoulos, A., \& Winklhofer, H. M. (2001). Index construction with formative indicators: An alternative to scale development. Journal of Marketing Research, 38(2), 269-277.

Ellis, P., \& Pecotich, A. (2001). Social factors influencing export initiation in small and medium-sized enterprises. Journal of Marketing Research, 38(1), 119-130.

Evans, J., Mavondo, F. T., \& Bridson, K. (2008). Psychic distance: Antecedents, retail strategy implications, and performance outcomes. Journal of International Marketing, 16(2), 32-63.

Festinger, L. (1957). A theory of cognitive dissonance. Evanston, IL: Row, Peterson.

Fiske, S. T., \& Neuberg, S. L. (1990). A continuum of impression formation, from categorybased to individuating processes: Influences of information and motivation on attention and interpretation. Advances in Experimental Social Psychology, 23(1990), $1-74$.

Francis, J. N. (1991). When in Rome? The effects of cultural adaptation on intercultural business negotiations. Journal of International Business Studies, 22(3), 403-428.

Golbeck, J. (2009). Trust and nuanced profile similarity in online social networks. $A C M$ Transactions on the Web (TWEB), 3(4), 12.

Hair, J. F., Black, W. C., Babin, B. J., \& Anderson, R. E. (2010). Multivariate Data Analysis. New Jersey, USA: Pearson Prentice Hall.

Harris, S., \& Wheeler, C. (2005). Entrepreneurs' relationships for internationalization: Functions, origins and strategies. International Business Review, 14(2), 187-207.

Hoffmann, J., Röttger, U., Ingenhoff, D., \& Hamidati, A. (2015). The rehabilitation of the "nation variable": Links between corporate communications and the cultural context in five countries. Corporate Communications: An International Journal, 20(4), 483499. 
Factors that Influence the Quality of Relationship between Exporters and Foreign Intermediaries in Relation to SMEs' Export Performance

Holm, D. B., \& Eriksson, K. (2000). The character of bridgehead relationships. International Business Review, 9(2), 191-210.

Ibeh, K., \& Kasem, L. (2011). The network perspective and the internationalization of small and medium sized software firms from Syria. Industrial Marketing Management, 40(3), 358-367.

Inkpen, A., \& Curall, S. (1998). The nature, antecedents, and consequences of joint venture trust. Journal of International Management, 4(1), 1-20.

Inkpen, A. C., \& Tsang, E. W. (2005). Social capital, networks, and knowledge transfer. Academy of Management Review, 30(1), 146-165.

Johanson, J., \& Vahlne, J. E. (1977). The internationalisation process of the firm-a model of knowledge development and increasing foreign market commitments. Journal of International Business Studies, 8(1), 23-32.

Johanson, J., \& Erik-Vahlne, J. (1990). The mechanism of internationalisation. International Marketing Review, 7(4), 11-24.

Katsikeas, C. S., Leonidou, L. C., \& Morgan, N. A. (2000). Firm-level export performance assessment: Review, evaluation, and development. Journal of the Academy of Marketing Science, 28(4), 493-511.

Krishnan, H. A., Miller, A., \& Judge, W. Q. (1997). Diversification and top management team complementarity: Is performance improved by merging similar or dissimilar teams? Strategic Management Journal, 18(5), 361-374.

Kogut, B., \& Kulatilaka, N. (1994). Operating flexibility, global manufacturing, and the option value of a multinational network. Management Science, 40(1), 123 - 139.

Kuhlmeier, B., \& David, G. K. (2010). The critical of relationship quality in small and medium sized enterprise internationalization. Journal of Global Marketing, 23(2010), 16-32.

Lages, L. F., Lages, C., \& Lages, C. R. (2005). Bringing export performance metrics into annual reports: The APEV scale and the PERFEX scorecard. Journal of International Marketing, 13(3), 79-104

Lages, L. F., \& Sousa, C. M. (2011). International Marketing. John Wiley \& Sons, Ltd.

LaBahn, D. W., \& Harich, K. R. (1997). Sensitivity to national business culture: Effects on U.S.-Mexican channel relationship performance. Journal of International Marketing, 5(4), 29-51.

Lee, J. (2018, January 1) SMEs need to rise to the challenge. The Star. Retrieved from https:/www.thestar.com.my/metro/smebiz/focus

Lew, Y., Sinkovics, R., \& Kuivalainen, O. (2013). Upstream internationalization process: Roles of social capital in creating exploratory capability and market performance, International Business Review, 22(6), 1101-1120.

Malaysia External Trade Development Corporation [MATRADE] (2014). New steps to boosts SMEs. The News Straits Times. Retrieved from http:/www.matrade.gov.my

Malaysia External Trade Development Corporation [MATRADE] (2014, October). Go-Exprogramme MATRADE. http://www.matrade.gov.my/exporters/go-ex-programme

Malaysia External Trade Development Corporation [MATRADE] (2017). MATRADE Media Release: MATRADE. Retrieved from http://www.matrade.gov.my

Meirovich, G. (2012). Cultural similarities and differences: Impacts on performance in strategic partnership. In Advances in Mergers and Acquisitions, 10, 55-74. 
Morgan, R. M., \& Hunt, S. D. (1994). The commitment-trust theory of relationship marketing. Journal of Marketing, 58(3), 20-38.

Musteen, M., Francis, J., \& Datta, D. K. (2010). The influence of international networks on internationalization speed and performance: A study of Czech SMEs. Journal of World Business, 45(3), 197-205.

Nahapiet, J., \& Ghoshal, S. (1998). Social Capital, intellectual capital, and the organizational advantage. Academy of Management Review, 23(2), 242-266.

Navarro, A., Losada, F., Ruzo, E., \& Díez, J. A. (2010). Implications of perceived competitive advantages, adaptation of marketing tactics and export commitment on export performance. Journal of World Business, 45(1), 49-58.

Navarro-García, A., Rondán-Cataluña, F. J., \& Acedo-González, F. J. (2013). The importance of an export-oriented culture for export performance. European Journal of International Management, 7(3), 1751-1757.

Nunnally, J. C., \& Bernstein, I. H. (1994). Psychometric Theory. rdsepiucsforg (Vol. 3, p.701). New York, NY: McGraw Hill. doi:10.1037/018882.

Pauline, V., Marloes, V. E., \& Stefan, M. (2013). Presumed cultural similarity paradox: Expatriate adjustment and performance across the border or over the globe. Journal of Global Mobility , 1(2), 219-238.

Peng, M. W., \& Ilinitch, A. Y. (1998). Export intermediary firms: A note on export development research. Journal of International Business Studies, 29(3), 609-620.

Peng, M. W., \& York, A. S. (2001). Behind intermediary performance in export trade: Transactions, agents, and resources. Journal of International Business Studies, 32(2), $327-346$.

Pinho, J. C. (2016). Social capital and export performance within exporter-intermediary relationships. Management Research Review, 39(4), 425 - 448.

Pinho, J. C. (2013). The role of relational social capital in examining exporter-intermediary relationships. European Business Review, 25(6), 553 - 570.

Pothukuchi, V., Damanpour, F., Choi, J., Chen, C. C., \& Park, S. H. (2002). National and organizational culture differences and international joint venture performance. Journal of International Business Studies, 33(2), 243-265.

Ringle, C. M., Wende, S., \& Will, A. (2005). SmartPLS 2.0 (M3) Beta.

Ripolles, M., Blesa, A., \& Monferrer, D. (2012). Factors enhancing the choice of higher resource commitment entry modes in international new ventures. International Business Review, 21(4), 648-666.

Robson, M. J., Skarmeas, D., \& Spyropoulou, S. (2006). Behavioral attributes and performance in international strategic alliances: Review and future direction. International Marketing Review, 23(6), 585-609.

Sakoa, M., \& Helperb, S. (1998). Determinants of trust in supplier relations: Evidence from the automative industry in Japan and the United States. Journal of Economic Behavior \& Organization, 387-417.

Saleh, M. A., Ali, M. Y., \& Julian, C. C. (2014). International buyer behaviour-commitment relationship: An investigation of the empirical link in importing. International Business Review, 23(2), 329-342.

Saleh, A. S., \& Ndubisi, N. O. (2011). An evalution of SME development in Malaysia. International Review of Business Research Papers, 2(1), 1-14 
Sarkar, M., Echambadi, R., Cavusgil, S. T., \& Aulakh, P. S. (2001). The influence of complementarity, compatibility, and relationship capital on alliance performance. Journal of the Academy of Marketing Science, 29(4), 358-373.

Senik, Z. C., Isa, R. M., Sham, R. M., \& Ayob, A. H. (2014). A model for understanding SMEs internationalization in emerging economies. Journal of Management, 41(2014), $25-42$.

Shenkar, O. (2001). Cultural distance revisited: Towards a more rigorous conceptualization and measurement of cultural differences. Journal of International Business Studies, $32(3), 519-535$.

Silva, S. C., Bradley, F., \& Sousa, C. M. (2012). Empirical test of the trust-performance link in an international alliances context. International Business Review, 21(2), 293-306.

Sirmon, D. G., \& Lane, P. J. (2004). A model of cultural differences and international alliance performance. Journal of International Business Studies, 35(4), 306-319.

Shoham, A. (1996). Marketing-mix standardization: Determinants of export performance. Journal of Global Marketing, 10(2), 53-73.

Sousa, C. M. (2004). Export performance measurement: An evaluation of the empirical research. Academy of Marketing Science Review, 2004 (1).

Stouraitis, V., Harun, M. H., \& Kyritsis, M. (2017). Motivators of SME initial export choice and the European Union regional effect in manufacturing. International Journal of Entrepreneurial Behavior \& Research, 23(1), 35-55.

Swift, J. S. (1999). Cultural closeness as a facet of cultural affinity: A contribution to the theory of psychic. International Marketing Review, 182 - 201.

Tsai, W., \& Ghoshal, S. (1998). Social capital and value creation: The role of intrafirm networks. Academy of Management Journal, 41(4), 464-476.

Wahid, R. R., Saidin, K., Arif, N. A., (2018). A clog on the right to quality education through OER: A case of Japan and Malaysia. Journal of International Studies, 14, 151-168.

Welch, L. S., Benito, G. R., \& Peterson, B. (2007). Foreign operation methods: Theory analysis and strategy. Cheltenham: Edward Elgar.

Wernerfelt, B. (1984). A resource-based view of the firm. Strategic Management Journal, 5(2), 171-180.

Wheelan, C. (2016). Informal social networks within and between organisations: On the properties of interpersonal ties and trust policing. An International Journal of Police Strategies \& Management, 39(1), 145-158.

Xie, X., Wu, Y., \& Zeng, S. (2016). A theory of multi-dimensional organizational innovation cultures and innovation performance in transitional economies: The role of team cohesion. Chinese Management Studies, 10(3), 458-479.

Yli-Renko, H., Autio, E., \& Sapienza, H. J. (2001). Social capital, knowledge acquisition, and knowledge exploitation in young technology-based firms. Strategic Management Journal, 22(6/7), 587-613.

Zikmund, W. G., Babin, B. J., Carr, J. C., \& Griffin, M. (2013). Business research methods. South Western: Chengage Learning. 